\title{
Laman Muka Blog koinkeadilan.com sebagai Bagian dari Gerakan Koin Peduli Prita Tahun 2009 (Analisis Wacana Kritis)
}

\author{
Era Bawarti \\ Program Studi Sastra Inggris, Fakultas Sastra \\ Universitas Al Azhar Indonesia, Jl. Sisingamangaraja, Jakarta 12110 \\ Penulis untuk korespondensi/E-mail: era.sugiri@uai.ac.id
}

\begin{abstract}
Abstrak - Penelitian ini menginvetigasi keberadaan sense kuasa dalam sebuah teks sebagai sebuah wacana. Korpus yang dipilih adalah teks laman muka blog koinkeadilan.com yang merupakan bagian dari Gerakan Koin Peduli Prita yang bergulir pada tahun 2009. Teks ini dianalisis lantaran mengandung sense kuasa di dalamnya. Teori yang melandasi analisis terhadap teks ini adalah teori analisis wacana kritis (AWK) oleh Fairclough, yang menyatakan bahwa teks pada hakikatnya adalah selain sebagai teks juga sebagai praktek diskursif dan praktek sosial. Metode penelitiannya adalah metode penelitian kepustakaan karena peneliti hanya berhadapan dengan teks yang siap pakai, merupakan data sekunder, dan tidak dibatasi oleh ruang dan waktu. Penelitian ini juga menggunakan metode kualitatif karena melibatkan prosedur pengumpulan data non-numerikal dengan hasil terbuka dan dianalisis menggunakan metode non-statistik, serta memiliki bentuk rumusan masalah yang deskriptif, karena masalah yang diteliti menuntut eksplorasi yang menyeluruh, luas, dan mendalam. Hasil analisis menunjukkan bahwa secara tekstual, teks ini menggunakan wording dan metafora serta transitivitas dan modalitas yang menampilkan sense kuasa; secara praktek diskursif, teks ini diproduksi, diedarkan, dan dikonsumsi sebagai kuasa, dengan menilik ciri koherensi dan intertektualitasnya; dan sebagai praktek sosial, teks ini berefek kuasa karena ia berhasil mempraktekkan proses hegemonik yang mempergilirkan kuasa, namun bukan melaluai kekerasan, melainkan melalui proses komunikasi dan argumentasi dalam ruang publik sebagaimana dijabarkan oleh Habermas.
\end{abstract}

Kata kunci-laman muka blog koinkeadilan.com, AWK, teks, praktek diskursif, praktek sosial, kuasa.

Abstract - This paper investigates the existence of the sense of power in a text as a discourse. Corpus chosen is the front page of blog koinkeadilan.com as part of Gerakan Koin Peduli Prita (Coins for Prita Movement). The text is analysed for it contains the sense of power. The theoretical background for the analysis is critical discourse analysis (CDA) by Fairclough. The method used is library reseach method, as the researcher has dealt with text only, which was ready-made, a secondary data, and unlimited in terms of time and space. Another method used is qualitative method, as the research has included nonnumerical data collection procedure, the result of which is open, the analysis used non-statistical method, and had a descriptive research question since it needs wholistic, wide, and deep exploration. The result shows that textually, the text used wordings, metaphors, transitivities, and modalities which represent the sense of power; as a discursive practice, the text was produced, circulated, and consumed as power based on its coherence and intertextuality features; and as a social practice, the text had power effect as it has successfully managed to practice hegemonic prosess by circulating power, yet not through violence but through communication and argumentation within a public sphere, as suggested by Habermas.

Keywords - the front page of blog koinkeadilan.com, CDA, text, discursive practice, social practice, power. 


\section{PENDAHULUAN}

\section{Latar Belakang}

$\mathrm{A}$ nalisis wacana kritis (AWK) adalah analisis yang berfokus terhadap wacana bukan semata sebagai studi bahasa berkenaan dengan aspek kebahasaannya saja melainkan juga dengan konteksnya (Eriyanto, 2000, hlm. 7). Tugas penting AWK adalah mengidentifikasi adanya hubungan antara wacana dan power sosial (Van Dijk, 1996, hlm. 85). Adapun pendekatan AWK berfokus pada peran wacana dalam produksi dan reproduksi dominansi serta tantangan terhadapnya, atau the role of discourse in the (re)production and challenge of dominance (Van Dijk, 2002). Dengan demikian, dalam AWK, teks tidak dilihat semata sebagai teks dengan berbagai perangkat tekstual dan strukturalnya, melainkan juga sebagai praktek kewacanaan dan konteks sosial yang melatarinya.

Korpus yang dianalisis dengan AWK dalam makalah ini adalah laman muka blog koinkeadilan.com. Blog ini sendiri lahir sebagai bagian dari sebuah gerakan sosial, atau fenomena sosial menurut AWK, yakni Gerakan Koin Peduli Prita yang mulai bergulir sejak Desember 2009. Dalam hal ini, laman muka blog koinkeadilan.com dipandang sebagai wacana yang dapat ditelaah menggunakan AWK, mengingat AWK selalu memandang wacana sebagai sebuah fenomena sosial dan, konsekuensinya, terus berupaya mengembangkan landasan teoritis berbasis teori sosial guna menempatkan wacana tersebut dalam masyarakat (Bloomaert, 2007, hlm. 27).

Gerakan Koin Peduli Prita ini sendiri muncul sebagai respon masyarakat atas vonis perdata terhadap Prita Mulyasari (32), terdakwa kasus pidana pencemaran nama baik yang merujuk kepada Pasal 27 ayat 33 UU ITE (Undang-Undang Nomor 11 tahun 2008 tentang Informasi dan Transaksi Elektronik). Vonis perdatanya sendiri berupa denda sebesar Rp 204 juta yang harus dibayarkan Prita kepada RS Omni Internasional Alam Sutera Tangerang, sebagai hukuman perdata lantaran Prita menurut pengadilan perdata terbukti telah mencemarkan nama baik RS tersebut melalui keluhannya di forum diskusi mailing list (milis) Sehat Group. Sebelumnya diketahui bahwa ditengarai menyampaikan keluhan terhadap layanan RS Omni Internasional Alam Sutera Tangerang dan dokter yang menanganinya melalui milis tersebut. Keluhan ini ditanggapi secara serius oleh pihak RS Omni Internasional Alam Sutera dengan melaporkan Prita ke pihak berwajib secara pidana dan perdata. Kasus inilah yang menggiring Prita pada keharusan membayar hukuman perdata tersebut. Dalam hal ini, masyarakat kemudian melihat bahwa vonis perdata ini merepresentasikan ketidakadilan yang bersumber dari ketimpangan relasi kuasa antara pasien dengan dokter/rumah sakit, dan oleh karenanya harus disikapi dengan perlawanan dalam bentuk gerakan sosial.

Lantaran segala silang-sengkarut kasus ini berawal dari diskusi di milis tersebut atau dengan kata lain berawal dari dunia maya, Gerakan Koin Peduli Prita sebagai respon masyarakat terhadap kasus perdata Prita ini kemudian mempublikasikan aktivitasnya sekaligus membagikan informasi akan kegiatan ini terutama melalui dunia maya pula, yakni lewat blog koinkeadilan.com. Gerakan ini sendiri berisikan ajakan kepada masyarakat untuk menyumbangkan sejumlah uang dalam bentuk koin untuk membantu Prita membayarkan vonis $\mathrm{Rp}$ 204 juta tersebut, dan blog ini berfungsi menyebarluaskan gerakan ini melalui dunia maya, khususnya melalui blog.

Istilah blog sendiri berasal dari kata web log, yang kemudian dikonjugasi menjadi weblog, yang diperingkas lagi menjadi blog (Notess, 2002, hlm. 70). Sebuah blog dapat didefinisikan sebagai situs web yang dikelola oleh pribadi-pribadi, bergaya buku harian (diary) atau personal journal dalam jaringan (daring) atau online, dan dengan entri yang kronologis dan singkat-singkat. Blog juga seringkali memuat ringkasan pelbagai berita serta tautan (link) ke situs-situs lain yang relevan. Dengan kata lain, blog adalah situs web pribadi yang memuat berbagai tulisan hasil pemikiran dan opini pencipta dan pengelolanya (selanjutnya disebut blogger), serta dilengkapi dengan tautan ke situs-situs lain yang berkaitan (lihat Vaezi, Torkzadeh, dan Chang, 2011, hlm. 35).

Komunitas blog disebut blogosphere. Adapun tujuan blog adalah salah satunya sebagai ruang bagi forum diskusi (discussion forum) (Ross, 2005, sebagaimana dikutip oleh Vaezi, Torkzadeh, dan Chang, 2011, hlm. 35) mengingat sifatnya yang interaktif, lantaran siapa saja dapat berpartisipasi di dalamnya dengan mengirimkan komentar terhadap posting yang dibuat oleh pengelola blog. Blog sendiri adalah situs dunia maya yang relatif mudah dibuat dan dirawat. Biaya yang dibutuhkan untuk mendirikan dan memelihara sebuah blog relatif kecil, bahkan tidak ada. 
Umumnya blog memiliki laman muka atau front page. Tujuannya untuk memperkenalkan blog ini kepada pembacanya. Blog juga memiliki kekhasan yakni bahwa di dalamnya terdapat modal sosial (social capital), yang bertumpu pada hubungan sosial (social connections), resiprositas, dan kepercayaan (trust) (Vaezi, Torkzadeh, dan Chang, 2011, hlm. 37). Dalam hal inilah, blog koinkeadilan.com menarik untuk dibedah dengan pisau AWK. Adapun fokus penelitian adalah pada laman mukanya, mengingat bagian inilah yang memperkenalkan konten blog secara keseluruhan sebagai bagian dari Gerakan Koin Peduli Prita.

Ketika blog koinkeadilan.com dibangun, kasus Prita sendiri tengah memasuki masa kritis. Sebagaimana telah disebutkan sebelumnya, Prita ketika itu telah dijatuhi hukuman perdata. Penjatuhan hukuman perdata bagi Prita sendiri ditengarai adalah guna mempengaruhi putusan pidananya yang ketika itu masih disidangkan. Dengan kata lain, karena secara perdata Prita telah dinyatakan bersalah, diharapkan secara pidana Prita juga akan dinyatakan bersalah sehingga akan dijatuhi hukuman badan berupa pemenjaraan (lihat "Uang Koin Peduli Prita: Prita Lelah Mencari Keadilan", Kompas, 5 Desember 2009). Ssebagai tambahan, selain hukuman denda, Prita juga dikenai hukuman perdata lainnya berupa keharusan memuat permohonan maaf resmi kepada RS Omni Internasional Alam Sutera berikut beberapa dokter yang namanya tersebut di dalam surat Prita di mailing list di dua surat kabar berskala nasional. Namun kedua hukuman ini akhirnya dibatalkan pelaksanaannya, seiring dengan reaksi keras masyarakat terhadap kasus ini.

Selanjutnya, sebagai informasi tambahan, blog ini sudah tidak aktif lagi seiring dengan berakhirnya kasus Prita dengan "kemenangan" di pihak Prita. Posting terakhirnya adalah tertanggal 17 Desember 2009 yang berisi informasi tentang akan digelarnya sebuah konser bertajuk "Konser Koin untuk Keadilan" pada 20 Desember 2010 di HardRock Café Jakarta.

\section{Masalah Penelitian}

Mengingat AWK mengemban tugas mengidentifikasi adanya hubungan antara wacana dan power sosial, serta meletakkan pengamatan terhadap wacana yang memproduksi dan mereproduksi dominansi, serta tantangan terhadap dominansi itu sendiri, penelitian yang menggunakan ancangan AWK ini berusaha menjawab pertanyaan sebagai berikut:
Bagaimanakah sense kuasa ditampilkan dalam wacana laman muka blog koinkeadilan.com secara tekstual, praktek diskursif, dan praktek sosial?

\section{Tujuan Penelitian}

Penelitian ini bertujuan untuk menginvestigasi keberadaan sense kuasa dalam laman muka blog koinkeadilan.com dengan analisis wacana kritis yang meliputi analisis tekstual wacana, analisis wacana sebagai praktek diskursif, dan analisis wacana sebagai praktek sosial.

\section{Manfaat Penelitian}

Penelitian ini bermanfaat bagi peneliti lain, terutama di bidang linguistik atau ilmu bahasa, yang bermaksud melakukan penelitian dengan ancangan AWK. Adapun bagi khalayak umum, penelitian ini berguna untuk mengetahui bahwa sebuah teks ternyata tidak hanya dapat ditelaah semata sebagai teks dengan segala perangkat tekstualnya, melainkan juga sebagai produk praktek kewacanaan, yang di dalamnya produksi teks, penyebarluasannya, serta konsumsinya, serta sebagai praktek sosial, yang artinya bahwa sebuah teks merupakan produk dari sebuah situasi sosial tertentu yang dapat dijelaskan menggunakan teori sosial, dan bukan semata sebagai produk kebahasaan.

\section{KERANGKA TEORI}

Wacana sebagai penggunaan bahasa menurut Fairclough (1992) selalu memiliki tiga dimensi. Pertama, wacana adalah teks atau berdimensi discourse-as-text. Kedua, wacana adalah praktek diskursif atau berdimensi discourse-as-discursivepractice. Terakhir, wacana adalah praktek sosial atau berdimensi discourse-as-social-practice.

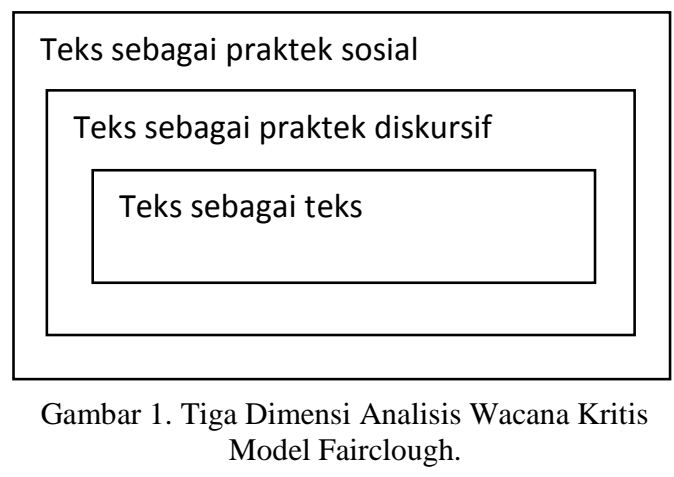

Dimensi wacana sebagai teks mencakup semua ciri dan pengaturan kebahasaan dari hal-hal yang konkret dalam wacana tersebut termasuk di 
dalamnya segala pilihan dan pola kosa kata, tata bahasa, kohesi serta struktur teks itu sendiri (Fairclough, 1992). Adapun dimensi wacana sebagai praktek diskursif melihat wacana sebagai sesuatu yang diproduksi, diedarkan, didistribusikan, dan dikonsumsi dalam masyarakat (Fairclough, 1992). Fairclough melihat proses ini dalam kerangka penyebarluasan sebuah objek kebahasaan konkret dengan memperhatikan segala ciri tindak tutur, koherensi, dan intertektualitasnya. Sementara dimensi wacana sebagai praktek sosial meliputi efek kuasa/ideologis dan proses hegemonik yang berhasil dioperasikan oleh teks tersebut (Fairclough, 1992).

\section{METODE PENELITIAN}

Penelitian ini merupakan studi kepustakaan, mengingat bahwa: (1) peneliti berhadapan langsung dengan teks dan bukan dengan pengetahuan langsung dari lapangan atau saksi mata; (2) data yang digunakan bersifat siap pakai (ready-made), yang artinya peneliti tidak pergi ke mana-mana, melainkan hanya berhadapan langsung dengan sumber yang sudah tersedia di perpustakaan; (3) data yang digunakan adalah sumber sekunder, dalam arti peneliti memperolehnya dari tangan kedua dan bukan data orisinil dari lapangan, dan (4) kondisi data tidak dibatasi oleh ruang dan waktu, yang artinya dalam hal ini peneliti berhadapan dengan informasi statik yang sudah tersimpan dalam rekaman tertulis sebagai data "mati" (Zed, 2014, hlm. 4-5). Dengan demikian, jelaslah bahwa metode penelitian yang digunakan adalah metode penelitian kepustakaan.

Penelitian ini juga bersifat kualitatif, karena melibatkan prosedur pengumpulan data nonnumerikal dengan hasil terbuka dan dianalisis menggunakan metode non-statistik (Dornyei, 2007), dan memiliki bentuk rumusan masalah yang deskriptif, karena masalah yang diteliti menuntuk eksplorasi yang menyeluruh, luas, dan mendalam (Sugiyomo, 2010).

\section{Korpus}

Korpus atau sumber data penelitian ini adalah laman muka blog koinkeadilan.com bertajuk "Halo Pendukung Prita!" Korpus ini dipilih karena menampilkan sense kuasa di dalamnya. Adapun bunyi teksnya secara utuh adalah sebagai berikut:
Koin keadilan: ketika keadilan direcehkan, kita pun mengumpulkan receh

Halo Pendukung Prita!

By admin | Published: 04/12/2009

Blog ini merupakan salah satu simpul informasi pengumpulan koin untuk mendukung Prita Mulyasari. Diharapkan sebelum keputusan Mahkamah Agung keluar, kita sudah mengumpulkan koin, dan hanya koin, untuk menggenapi pembayaran ganti rugi yang dijatuhkan kepada Prita senilai Rp 204 juta.

Tentang cara, kita bisa dan boleh berbeda pendapat. Misalnya tentang perlu atau tak perlu dalam pengumpulan koin. Yang pasti kita samasama di posisi ini: rasa keadilan kita terlukai. Spirit kita pun sama, bahwa keangkuhan kekuasaan yang ingin mengenyahkan kebebasan berpendapat melalui kriminalisasi harus kita lawan.

Kita membela Prita dan kebebasan berpendapat. Sekarang Prita, esok entah siapa.

Salam koin.

free prita by kdri wahyu adityaBlog

Data dipilah-dipilah dari korpus ini sesuai dengan tahapan tersebut di atas, lalu ditelaah menggunakan ancangan AWK Fairclough.

\section{Tahapan}

Karena penelitian ini mengacu pada pendekatan AWK berdasarkan teori Fairclough (1992), maka metode penelitiannya melampaui tiga tahap, yakni (1) tahap deskripsi, yang berfokus pada bagaimana segala ciri kebahasaan-tekstual dari data dideskripsikan; (2) tahap interpretasi, yang berfokus pada bagaimana data diinterpretasi berdasarkan sumber-sumber kognitif, sosial, dan ideologis penulis wacana; dan (3) tahap eksplanasi, yang berfokus pada bagaimana deskripsi teks berikut interpretasinya dieksplanasi dengan teori sosial tertentu (Bloomaert, 2007, hlm. 30).

Pada tahap deskripsi, peneliti menelaah diksi dan pola kosa kata dengan berfokus pada wording, metafora, dan tata Bahasa, sebagai ciri tekstualkebahasaan teks ini. Kohesi leksikal berupa kata koin, Prita, dan kita menunjukkan elemen kewacanaan. Pada tahap ini, peneliti mendapati pula bahwa diksi kita menunjukkan aspek tenor solidaritas sebagaimana yang dikemukaan Halliday 
dan Hasan (1976), sekaligus aspek kuasa karena penulis dalam posisi mengajak pembaca berpartisipasi dalam gerakan koin. Peneliti juga berhasil memilah berbagai ekspresi figuratif yang bersifat metaforis sebagai elemen stilistika teks yang menggugah pembaca sehingga kemudian bersedia melakukan ajakan penulis. Di sini elemen stilistis ini ternyata juga menampilkan efek kuasa. Lebih lanjut, peneliti juga berhasil mengidentifikasi aspek transitivitas (ada atau tiadanya aktor penyebab/pelaku) dan aspek modalitas yang menunjukkan sense kuasa.

Pada tahap interpretasi, teks dianalisis sebagai sebuah praktek diskursif. Peneliti menemukan ciri koherensi, yakni pengetahuan yang sama (shared knowledge) antara penulis dan pembaca tentang sesuatu yang berada di luar teks. Hal ini tampak dari deretan komentar dari pembaca laman muka ini. Peneliti juga berhasil menginventarisir keberadaan intertekstualitas, yakni suatu keadaan ketika teks dibuat berdasarkan teks yang sudah ada sebelumnya. Kedua elemen ini menunjukkan kemampuan penulis menghadirkan kuasa melalui praanggapan atau pengetahuan bersama.

Pada tahap terakhir atau tahap eksplanasi, peneliti mengaitkan teks dengan teori sosial kritis Habermas, yang mengedapankan komunikasi, dan bukan revolusi, sebagai elemen praksis yang bernarasi kuasa. Hal ini berarti teks ini menempuh jalur dialog dan bukan kekerasan sebagai jalan menampilkan kuasanya.

\section{HASIL DAN PEMBAHASAN}

\section{Dimensi Wacana sebagai Teks}

Analisis terhadap wacana sebagai teks difokuskan pada diksi dan pola kosa kata yang ditampilkan di dalamnya. Dalam hal ini, analisisnya difokuskan pada wording dan metafora. Analisis diksi juga dilakukan terhadap aspek gramatikal teks, yang dipersempit hanya pada aspek transitivitas dan modalitasnya.

Wording adalah pilihan kata dan struktur gramatikal yang membentuk format leksikogramatikal sebuah teks (Halliday \& Hasan, 1976, hlm. 6). Pilihan kosa kata koin dan Prita yang direpetisi di sepanjang teks menunjukkan kohesi leksikal yang membuat teks ini dapat dikategorikan sebagai wacana, demikian pula dengan pilihan pronomina kita yang menunjukkan partisipan dalam wacana, yakni penulis dan juga (diharapkan) pembaca. Sense solidaritas sebagai tenor wacana terasa kuat, sekaligus penulis menunjukkan kuasanya untuk mengajak pembaca berpastisipasi dalam gerakan ini. Menurut Halliday \& Hasan (1976), tenor mengacu pada siapa saja yang terlibat dalam wacana dengan segala sifat, status dan peran antarmereka, dan dapat dianalisis berdasarkan kategori kuasa (power) dan jarak sosial (social distance) (Renkema, 2004, hlm. 46), sehingga dari situ tergambar apakah hubungan antarpartisipan merupakan bentuk relasi kuasa atau solidaritas. Dalam teks ini, tenor yang digunakan adalah solidaritas, namun bernuansa kuasa karena sifatnya yang mengajak.

Adapun metafora menurut Newmark (1988, hlm. 104) adalah "segala ekspresi figuratif" berupa: kata dengan sense yang dipindahkan, personifikasi sebuah abstraksi, serta kata atau kolokasi yang dimaknai tidak dalam makna literalnya. Dalam teks ini ditemukan tiga konstruksi yang mengandung metafora berupa personifikasi abstraksi, yakni "keadilan direcehkan", "rasa keadilan terlukai", serta "keangkuhan kekuasaan". Perhatikan bahwa pilihan kata "direcehkan" dan "terlukai", yang mengikuti kata "keadilan" dan frase "rasa keadilan" serta kata "keangkuhan" yang diikuti kata "kekuasaan" menampilkan sense ketertindasan kepada pembaca, dan efeknya adalah perasaan ingin melawan ketertindasan itu. Di sini penulis menampilkan kuasanya untuk mengajak pembaca "melawan" ketertindasan itu dengan berpartisipasi dalam gerakan koin.

Lebih lanjut, secara tata bahasa, teks dapat dikritisi melalui transitivitas dan modalitasnya. Transitivitas berkaitan dengan perbedaan antara tindakan (dengan aktor sebagai penyebab) dan peristiwa (tanpa aktor sebagai penyebab atau pelaku). Jika ditilik dari struktur fungsi semantisnya, hampir semua klausa dan/atau kalimat dalam teks menunjukkan adanya agen (pelaku)(lihat Kridalaksana, et al., 1999, hlm. 136), yakni "siapa" melakukan "apa". Fungsi semantis di sini adalah merujuk kepada klasifikasi fungsi berdasarkan mazhab fungsional Halliday, yang mendedah kalimat atau klausa berdasarkan fungsi sintaktis, semantis, dan pragmatis (Kridalaksana, et al., 1999, hlm. 129-143). Mengapa analisis fungsi dianggap penting dalam tahap ini? Tak lain lantaran dalam analisis dimensi teks-nya ancangan AWK Fairclough bertumpu pada alat analisis berbasis tekstual-kebahasaan (linguistic-textual), atau secara lebih spesifik berlandaskan pada linguistik 
sistemik-fungsional mazhab Halliday (lihat Bloomaert, 2007, hlm. 34). Adapun keberadaan agen sebagaimana disebutkan di atas sudah tampak semenjak dari tagline-nya yang diwakili oleh kata kita. Kata kita sebagai agen ini muncul berkali-kali, seperti dalam kalimat "[...] kita sudah mengumpulkan koin [...]", "Tentang cara, kita bisa dan boleh berbeda pendapat", dan lain-lain. Dengan demikian dapat dikatakan bahwa penulis teks menampilkan kuasa mengajak pembaca menjadi agen/pelaku bagi gerakan ini. Pembaca dipengaruhi untuk yakin bahwa mereka juga merupakan agen/pelaku dalam gerakan ini dengan penggunaan kata kita ini.

Meskipun demikian, teks ini memiliki pula beberapa bentuk non-agentif (tidak menyebut pelaku) seperti dalam konstruksi klausal "ketika keadilan direcehkan [...]", yang bermakna "ada yang merecehkan keadilan", konstruksi "Diharapkan sebelum keputusan Mahkamah Agung keluar, [...]", yang bermakna bahwa "ada yang mengharapkan", atau frase "[...] ganti rugi yang dijatuhkan kepada Prita", yang bermakna "ada yang menjatuhkan (hukuman ganti rugi) kepada Prita" atau konstruksi klausal "[...] rasa keadilan kita terlukai", yang bermakna "ada yang melukai rasa keadilan". Agen dalam keempat konstruksi ini tidak disebutkan, yang menandai bahwa peristiwa terjadi tanpa agen yang bertanggung jawab (without responsible agent). Dalam hal ini, agaknya ketiga klausa bertujuan untuk menekankan pada efek (Jørgensen\& Phillips, 2002, hlm. 83). dan bukan pada tindakan yang dilakukan.

Adapun modalitas didefinisikan sebagai segala ekspresi kebahasaan yang menunjukkan konsep permission (ijin), necessity (keharusan), dan ability (kemampuan) yang dapat dikategorikan sebagai modal (Tallerman, 1988, hlm. 66). Modal berfungsi sebagai kata pelengkap (auxiliary), yang berasal dari konsep mood, yakni sebuah kategori gramatikal yang memarkahi kelengkapankelengkapan kebahasaan seperti possibility (kemungkinan), probability (kemungkinan berdasarkan perhitungan) atau certainty (kepastian) (Tallerman, 1988, hlm. 55). Kategori gramatikal ini muncul karena bahasa, bahasa apapun, pada hakikatnya cenderung membedakan peristiwa aktual dan hipotetikal (Tallerman, 1988, hlm. 55). Artinya bahwa perbedaan antara yang aktual dengan yang hipotetikal dapat ditunjukkan melalui bahasa dengan permarkahan berupa kata pelengkap modal.
Dalam teks ini, ekspresi kebahasaan yang menunjukkan modalitas tampak dalam kata bisa dan boleh dalam kalimat "Tentang cara, kita bisa dan boleh berbeda pendapat". Di sini modalitas menunjukkan ekspresi kebahasaan berupa permission untuk "berbeda pendapat tentang cara", yang bermakna bahwa penulis berkuasa mengijinkan pembaca untuk memilih "perlu atau tidak mengumpulkan koin untuk membantu Prita". Penulis teks juga menekankan kesamaan posisi dalam kasus Prita yang ditegaskan dalam kalimat berikutnya "Yang pasti kita sama-sama di posisi ini: [...]". Dari kalimat ini tampak bahwa penulis melakukan positioning yang sama dengan pembaca dalam kasus Prita, yakni mendukung Prita, sekaligus menampilkan kuasa untuk meyakinkan pembaca bahwa mereka ada di posisi yang sama. Namun penulis teks juga menggunakan kata harus dalam kalimat "[...] melalui kriminalisasi harus kita lawan". Dalam hal ini ada sesuatu yang obligated atau diharuskan kepada pembaca, yakni perbuatan melawan. Kata harus ini menampilkan sense kuasa penulis teks terhadap pembacanya. Positioning sendiri didefinisikan sebagai bagaimana hubungan yang kita bangun melalui tindakan yang direalisasikan secara kebahasaan (linguistically realized action) dan interaksi dengan faset-faset yang berbeda dalam lingkungan sosial, budaya, dan ideologis dapat bersumbangsih terhadap identifikasi "siapa kita" (lihat De Fina, Schiffrin, \& Bamberg, 2006, hlm. 7). Konsep positioning ini kemudian erat kaitannya dengan konsep "identitas" dalam wacana.

Dari ketiga poin di atas, yakni wording, metafora, serta pilihan kosa kata agentif/non-agentif serta kata kerja modal, dapat disimpulkan bahwa teks ini secara tekstual-kebahasaan bernuansa kuasa.

\section{Dimensi Wacana sebagai Praktek Diskursif}

Teks laman muka blog koinkeadilan.com tidak mungkin diproduksi tanpa adanya sebuah proses diskursif yang melatarinya. Kasus Prita yang divonis perdata harus membayar denda sejumlah Rp 204 juta menjadi stimulus bagi diproduksinya teks ini, sehingga ia kemudian harus dilihat dalam kerangka penyebarluasan sebuah objek kebahasaan konkret dengan memperhatikan ciri koherensi dan intertektualitasnya. Produksi ini kemudian dikonsumsi oleh pembaca dan pada gilirannya menghasilkan sebuah proses diskursif berupa komentar dari pembaca teks, sebagaimana berikut: 
prajnamu

Posted 05/12/2009 at 01.27.10 | Permalink

Ada yang merecehkan keadilan, beri mereka recehan!*tweet @enda ya?*

hlasmana

Posted 05/12/2009 at 13.41.04 | Permalink

maju terus! beri peringatan pada mereka yg merecahkan keadilan.

sugianto setiawan

Posted 05/12/2009 at 22.18.44 | Permalink

Demi uang, keadialn telah di korbankan, hati nurani sudah tak ada lagi bagi penegak hukum di negeri ini, mereka tak pernah berpikir tentang karma yang mereka pikirkan hanya uang daqn harta .untuk rakyat kecil bersatu melawan kejoliman penegak hukum di negeri .semoga allah memberikan ajab yang pedih ingat masih ada kehidupan setelah kematian.

yr

Posted 06/12/2009 at 03.29.26 | Permalink

Doa kami selalu menyertaimu Bu Prita...

alfian

Posted 07/12/2009 at 08.33.21 | Permalink

Untuk bu Prita "Tabahkan hati mu" . Memang keadilan di Republik ini tdk pernah \& tidak akan berpihak kepada Qta, selama qta msh jd org kecil dan hanya uang \& kekuasaan yg bs berbicara.

soejatmixo

Posted 07/12/2009 at 18.04.13 | Permalink

Klo dah ngumpul smua uangnya, mungkin lebih baik klo penyerahan uangnya berbentuk koin smua aja, jadi 204juta berbentuk koin smua di bayarkan ke pengadilan.. PISS and Love

luigi pralangga

Posted 07/12/2009 at 20.13.26 | Permalink

Insyallah pas cuti nanti akan ikut nyumbang si koinkoin itu.. memang disayangkan kalau peradilan kita masih 'tebang pilih' dalam urusan rakyat kecil melawan 'korporasi' - semoga peradilan ini bisa berkaca bahwasanya hakin yang tidak amanat itu siksa di akhiratnya beraaat!.

sabar ya...bu Prita,inilah keadilan yang kita rasakan di indonesia.

qosim

Posted 07/12/2009 at 20.54.47 | Permalink

Tegakkan keadilan di Indonesia! Tetap tabah Ibu Prita. Doa kami menyertaimu

budhi k.wardhana

Posted 10/12/2009 at 18.57.50 | Permalink

- buat Mas Gembol, minta ijin untuk menampilkan ikon ini di blog saya. teyzar

Posted 13/12/2009 at 15.08.38 | Permalink

saya salut dengan ibu prita yang selalu tegar menghadapi RS yang kurang sopan terhadap sang pasien............... q dukung trs ibu prita PISs.......... Good luck my mom..................

candra

Posted 23/12/2009 at 14.02.50 | Permalink

Alhamdulillah, lewat ibu akan membuka jalan keadilan bagi kita semua...

Di Indonesia Hukum cuma tajam bagi kaum miskin/umum seperti apa yang terjadi dengan maba Prita juga terjadi dengan Saya. Yang saya hadapi adalah perusahaan raksasa di Indonesia yakni Sinar Mas Group/PT. Pindo Deli penghasil kertas terbesar di Indonesia. Kita berharap dengan gerakan koin peduli ini meningkatkan solidaritas kita dalam memperjuangkan keadilan.Oh iya bagaimana saya mendapatkan dukungan seperti mba Prita ya?

\section{alfitri satria}

Posted 24/12/2009 at 11.28.53 | Permalink

Di Indonesia Hukum cuma tajam bagi kaum miskin/umum seperti apa yang terjadi dengan maba Prita juga terjadi dengan Saya. Yang saya hadapi adalah perusahaan raksasa di Indonesia yakni Sinar Mas Group/PT. Pindo Deli penghasil kertas terbesar di Indonesia. Kita berharap dengan gerakan koin peduli ini meningkatkan solidaritas kita dalam memperjuangkan keadilan.Oh iya bagaimana saya mendapatkan dukungan seperti mba Prita ya?

Tanggapan ini kesemuanya menunjukkan keberpihakan pada Prita, yang dengan kata lain mengimplikasikan keberhasilan pererdaran dan penyebarluasan teks, sekaligus keberhasilan penulis teks menampilkan kuasa dalam relasi sosial dengan pembaca.

Gerakan koin ini sendiri, berikut blog koinkeadilan.com sebagai bagiannya, adalah sebuah peristiwa komunikasi (communicative event). Konsep komunikasi itu sendiri menurut Hoffman (1993) dapat digambarkan sebagai sebuah proses yang terjadi antara dua pihak, dengan satu pihak menghasilkan tuturan (dalam bahasa lisan), gerakan tangan (dalam bahasa isyarat), atau tulisan (dalam bahasa tulis), yang disebut pengirim, sementara pada saat yang bersamaan pihak lain menyimak (tuturan atau gerakan tangan) atau membaca (tulisan), yang disebut penerima. Hoffman (1993) menegaskan bahwa tidak akan ada komunikasi kecuali si penerima memperoleh gagasan yang dimaksudkan oleh si pengirim (melalui tuturan, gerakan tangan, atau tulisan) tersebut (lihat Hoffman, 1993, hlm. 4). Dengan demikian, gerakan koin berikut blog 
koinkeadilan.com merupakan peristiwa komunikasi, mengingat di dalamnya ada pesan yang ingin disampaikan oleh penggagas gerakan ini, atau dengan kata lain ada paket informasi yang harus ditransmisikan dari satu pihak ke pihak lain (Renkema, 2004, hlm. 40), yang kemudian diwujudkan dalam bentuk kalimat-kalimat yang akhirnya membentuk sebuah teks, dalam hal ini teks laman muka blog koinkeadilan.com sebagai bagian dari gerakan koin.

Teks sendiri dalam konsep ilmu bahasa (linguistik) merujuk pada passage apapun, baik lisan maupun tertulis, dengan panjang berapapun, yang membentuk sebuah kesatuan utuh. Sebuah teks haruslah dipandang sebagai sebuah unit semantis, yakni sebuah satuan unit, bukan berdasarkan bentuk melainkan berdasarkan makna. Dengan kata lain, sebuah teks bukanlah sesuatu yang terdiri dari kalimat-kalimat, melainkan sesuatu yang direalisasikan dalam kalimat-kalimat (lihat Halliday \& Hasan, 1976, hlm. 1-2). Dalam hal ini, teks laman muka blog koinkeadilan.com merupakan sesuatu yang direalisasikan dalam kalimat-kalimat, karena merupakan satu unit semantis yang utuh, sekaligus merupakan peristiwa komunikasi, lantaran ada pesan yang dikirim dan diterima.

Oleh karena merupakan bagian dari sebuah peristiwa komunikasi, teks senantiasa memiliki koherensi, yakni hubungan (connection) yang disebabkan oleh sesuatu di luar teks, biasanya berupa pengetahuan yang diasumsikan atau dipraanggapkan sudah diketahui oleh pembaca teks (Renkema, 2004, hlm. 49), dengan text world-nya. Dalam hal ini penulis teks mengasumsikan atau mempraanggapkan pembaca teks sudah memiliki pengetahuan mengenai kasus Prita.

Koherensi dengan pengetahuan di luar teks ditunjukkan oleh pilihan kosakata seperti kata Prita, keadilan, kebebasan berpendapat, $R p 204$ juta, dan kriminalisasi. Adapun kosakata seperti koin dan receh merupakan bentuk "wacana" baru yang yang ditawarkan oleh teks ini sebagai bagian dari apa yang disebut Fairclough (1995) sebagai interdiskursivitas, yakni sebuah aspek hubungan antarwacana yang terjadi sebagai respon atas wacana sebelumnya dalam sebuah peristiwa komunikasi (Jørgensen \& Phillips, 2002, hlm. 73). Kata koin dan receh menunjukkan ada "wacana" yang ditawarkan teks ini, yakni membantu Prita membayar ganti rugi yang dibebankan kepadanya, dan bantuan itu harus berupa koin atau receh. "Wacana" ini merupakan respon terhadap "wacana" lain yang memerintahkan Prita untuk membayar sejumlah uang, sekaligus merepresentasikan protes penulis teks terhadap wacana Prita harus membayar Rp 2004 juta.

Sebagai sebuah praktek diskursif, teks ini memiliki apa yang disebut oleh Fairclough (1992) sebagai aspek intertekstualitas, yakni sebuah kondisi ketika sebuah peristiwa komunikasi bersumber dari peristiwa yang mendahuluinya (Jørgensen \& Phillips, 2002, hlm. 73). Dalam konteks ini, secara kebahasaan, teks ini banyak bersumber dari elemen kebahasaan yang sudah digunakan sebelumnya, seperti kosakata tersebut $\mathrm{di}$ atas. Elemen kebahasaan ini mencerminkan kognisi penulis teks terhadap materi yang ditulis dalam teks, ide perubahan sosial yang diusung penulis teks (yakni bahwa "mengumpulkan receh adalah untuk mengubah kondisi sosial yang sebelumnya tidak berpihak pada Prita menjadi berpihak pada Prita"), dan afiliasi ideologis penulis teks, yang merupakan bentuk tantangan terhadap dominansi atau challenge of dominance menurut Van Dijk (1996). Dominance sendiri didefinisikan sebagai sebentuk social power abuse (penyalahgunaan kuasa sosial) yang pada gilirannya mempraktekkan tindakan mengontrol pihak lain berdasarkan kepentingannya sendiri. Tindakan mengontrol ini baik secara legal maupun moral tidak terlegitimasi serta kerapkali menghasilkan social inequality (ketidaksetaraan sosial) (lihat Van Dijk, 1996, hlm. 84).

Sebagai simpulan bagian ini, tampak jelas bahwa penulis teks memiliki kuasa untuk mempengaruhi pembaca dengan "wacana" yang diwujudkannya dalam serangkaian elemen kebahasaan konkret yang tidak hanya berkohesi melainkan juga berkoherensi dan intertekstual, berupa teks laman muka blog koinkeadilan.com ini, berdasarkan kognisi, kesadaran sosial, serta afiliasi ideologisnya.

\section{Dimensi Wacana sebagai Praktek Sosial}

Wacana dapat dilihat pula sebagai faktor pembentuk (constitutive factor) bagi relasi social (Renkema, 2004, hlm. 238). Praktek diskursif dari suatu wacana bersumbangsih terhadap penciptaan dan reproduksi hubungan kuasa yang tidak sejajar (unequal power relation) antarkelompok sosial (Jørgensen \& Phillips, 2002, hlm. 63). Dengan kata lain, penciptaan dan reproduksi hubungan kuasa yang tidak sejajar ini merupakan efek dari praktek diskursif, yang dikenal pula sebagai efek ideologis (Jørgensen \& Phillips, 2002, hlm. 63). Lebih lanjut, kehadiran teks laman muka blog koinkeadilan.com 
ini harus dilihat dari sudut pandang bahasa, komunikasi, dan identitas menurut pascastrukturalis, yakni bahwa selalu ada social turn dalam ilmu bahasa dan sebaliknya selalu ada linguistic turn dalam ilmu sosial (Maybin, 2002, hlm. 64).

Pendekatan ini merupakan karya Bakhtin dan Volosinov yang merupakan oposan dari pendekatan strukturalis Saussure. Kedua sarjana ini meyakini bahwa bahasa harus dipahami sebagai sebuah realitas konkret yang hidup. Hal ini bertentangan dengan pandangan Saussurean yang menyatakan bahasa dikonseptualisasikan sebagai sebuah sistem tanda yang abstrak yang makna setiap elemennya berasal dari oposisinya terhadap elemen lain (lihat Maybin, 2002, hlm. 64). Menurut Bakhtin dan Volosinov, teks harus dipahami sebagai sesuatu yang merespon dan/atau mengantisipasi teks lainnya, karena teks sebagai wacana merupakan sebuah sistem representasi (Foucault, 1980, dikutip oleh Hall, 2002, hlm. 76). Artinya, wacana bukan semata tentang bahasa, melainkan juga tentang practice (praktek), sehingga pasti merepresentasikan sebuah pesan yang merupakan sebuah practice, dalam hal ini praktek diskursif. Penulis teks dalam hal ini sadar bahwa ia memiliki pengetahuan (knowledge) akan kasus ini, dan dengan pengetahuan ini ia membangun relasi kuasa melalui pemroduksian teks yang pada gilirannya mengintrodusir ideologinya melalui proses diskursif yang dibawa oleh teks tersebut. Hal ini sejalan dengan pemikiran Foucault (1980) yang menyatakan bahwa pengetahuan (knowledge) bertautan dengan kuasa karena bukan hanya dapat mengakuisisi kebenaran (the truth), tapi juga dapat "berkuasa" membuat dirinya "benar" (make itself true) (lihat Hall, 2002, hlm. 76).

Salah satu elemen yang juga penting dalam upaya membangun relasi kuasa dalam kasus ini adalah dengan simbol non-kebahasaan. Bahasa gambar ini ternyata memainkan peran penting dalam memperkokoh penyebarluasan proses hegemonik teks. Contoh gambarnya adalah sebagai berikut:

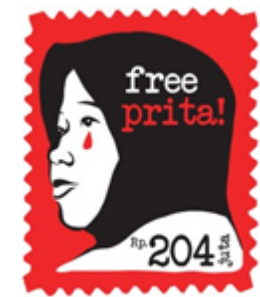

Gambar 2. Free Prita!

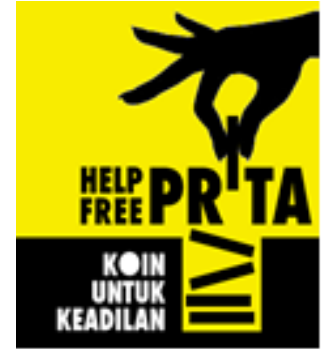

Gambar 3. Help Free Prita: Koin untuk Keadilan

Proses teks menjadi hegemon terbantu dengan gambar-gambar banner semacam ini, walaupun dalam penelitian ini tidak akan dibahas lebih lanjut. Akan tetapi sebagai sebuah praktek sosial, teks didampingi dengan banner yang merepresentasi ide yang dimaksud akan membantu tercapainya tujuan sosial, yakni mempergilirkan kuasa.

Proses hegemonik teks ini sendiri terlihat dari bagaimana ide pengumpulan koin guna membayar hukuman denda yang dijatuhkan kepada Prita kemudian menjadi isu besar dan kemudian menjadi gerakan besar yang menghegemoni sistem sosial pada kurun waktu itu. Tidak hanya itu. Dikaitkan dengan teori sosial sebagai suatu keharusan dalam AWK, gerakan pengumpulan koin ini berhasil pula menjadi sebuah tindakan komunikatif sebagaimana merujuk pada teori kritis Habermas, dalam konteks bahwa gerakan koin menjadi sebuah argumentasi dalam sebuah masyarakat komunikatif, yakni masyarakat yang melakukan kritik bukan melalui revolusi atau kekerasan, melainkan melalui argumentasi dalam sebuah ruang publik politik -tempat bagi publik dalam mengekspresikan kebebasan dan otonomi mereka (lihat Kusuma, 2010). Gerakan Koin Peduli Prita bersifat sangat simbolik, di mana koin berperan sebagai argumentasi dalam diskursus ruang publik untuk menyatakan pendapat dan keberpihakan publik dalam kasus ini sebagaimana teori Habermas. Teori Kritis Habermas sendiri merupakan teori yang menjawab kebuntuan rasionalitas instrumental pendahulunya, yakni para teoritisi kritis Mazhab Frankfurt. Dalam teori Habermas, rasio memperoleh pemahaman baru yakni sebagai hal yang berkaitan dengan kemampuan linguistik manusia. Sebagai ganti dari paradigma praksis sebagai kerja, Habermas mengemukakan paradigma baru yakni praksis adalah komunikasi, yang implikasinya adalah pemahaman baru bahwa praksis emansipatoris merupakan dialog komunikatif dan tindakan komunikatif yang menghasilkan pencerahan (Hardiman, 2009, hlm. 91) Hal ini tentu saja bertolak belakang dengan 
teori Marxis yang memprasyaratkan jalan revolusioner untuk menjungkirbalikkan struktur masyarakat demi terciptanya masyarakat sosialis yang dicita-citakan karena dengan paradigma komunikasi ini Habermas menempuh jalan konsensus dengan tujuan terciptanya demokrasi radikal, yakni hubungan sosial yang terjadi dalam lingkup komunikasi yang bebas penguasaan (Hardiman, 2009, hlm. 91). Menurut Heller (1981), dalam konteks komunikasi, apa-apa yang disebut perjuangan kelas dalam pandangan klasik diganti dengan perbincangan rasional di mana argumen berperan sebagai unsur yang emansipatoris (lihat Thompson, (ed.), 1982, hlm. 24-27). Oleh karena itu, selain bersifat simbolik, Gerakan Koin ini juga sangat kritis karena mengusung nilai emansipatoris yang mencerahkan sehingga akhirnya publik mengetahui duduk perkaranya di permukaan, menangkap esensi dari kasus ini di bawah permukaan, dan merasa berkepentingan untuk terlibat secara baik langsung maupun tidak langsung dalam diskursus ruang publik ini dengan berpartisipasi secara argumentatif simbolis melalui koin, yang berbuah perkara perdata Prita dibatalkan karena pihak RS Omni mencabut gugatan perdatanya, yang dinyatakan secara resmi dalam sebuah jumpa pers oleh Direktur RS Omni Internasional Alam Sutera, Bina Ratna Kusuma Fitri, pada tanggal 11 Desember 2009 (lihat "Prita Ingin Perkara Pidana Juga Dicabut: RS Omni Internasional Alam Sutera Cabut Gugatan Perdata" Kompas, 12 Desember 2009). Dengan demikian teks laman muka blog koinkeadilan.com ini berhasil menegaskan dirinya sebagai wacana kekuasaan karena dengannya sebuah perubahan sosial dihasilkan, sekaligus sebagai wacana yang berperan dalam menjadi tentangan bagi dominansi, atau as a challenge of dominance (lihat Van Dijk, 2002, hlm. 300) - dalam hal ini hukum formal.

\section{KESIMPULAN}

Sebagai sebuah teks yang dianalisis dengan pisau AWK Fairclough (1992), teks laman muka koinkeadilan.com berhasil menampilkan sense kuasa dalam ketiga dimensi yang diprasyaratkan, sebagai berikut:

1.Teks ini merupakan wacana ber-sense kuasa dari sisi aspek kebahasaannya. Dari sisi pilihan diksi dan pola kosa kata berupa wording, metafora, dan aspek gramatikal berupa elemen transitivitas dan modalitas, semuanya memperlihatkan sense kuasa. Diksi berupa koin, Prita, dan kita direpetisi terus-menerus sehingga membentuk kohesi leksikal yang merupakan elemen penting dalam pembentukan wacana. Kata kita sendiri menunjukkan tenor solidaritas namun efeknya kuasa, karena sifatnya yang mengajak. Elemen metafora sebagai unsur stilistis ternyata juga berperan kuasa, lantaran menggunakan diksi metaforis yang kuat dan mempengaruhi. Adapun elemen transitivitas yang agentif menunjukkan kuasa karena penggunaan pronomina kita yang bersifat menempatkan pembaca sebagai bagian dari penulis, sedangkan yang non-agentif juga bernuansa kuasa karena menekankan pada efek yang ditimbulkan pada diri pembaca setelah membaca teks ini.

2.Sebagai praktek diskursif yang menjembatani aspek kebahasaannya dengan praktek sosialnya, teks ini juga bernuansa kuasa, karena elemen koherensi dan intertekstualitasnya, baik di tataran produksi maupun konsumsi teks sebagai praktek diskursifnya, menunjukkan bahwa penulis teks berhasil memperlihatkan kuasa. Hal ini ditunjukkan melalui kesetujuan sidang pembaca terhadap konten teks, yang diejawantahkan dalam bagian komentar. Koherensi dan intertekstualitas teks juga menunjukkan bahwa pengetahuan bersama dan praanggapan penulis dan pembaca teks adalah sama, dengan pembaca teks sebagai pihak yang bersetuju terhadap penulis teks.

3. Sebagai praktek sosial yang dijalankannya, teks ini berhasil melemparkan sebuah wacana antidominansi yang pada akhirnya mempergilirkan kuasa dari pihak yang "secara absah berkuasa" kepada publik yang mengkritisi kasus ini. Kuasa ini pada akhirnya terlihat dari kemenangan Prita dalam kasus ini, dengan dicabutnya gugatan perdata dan dibatalkannya kasus pidananya. Teks sebagai bagian dari Gerakan Koin Peduli Pritas sebagai sebuah gerakan sosial, memperlihatkan kuasa tidak melalui jalan kekerasan atau revolusi, melainkan melalui jalan komunikasi dan argumentasi di ruang publik sebagaimana yang ditawarkan Habermas melalui teori kritisnya. Dengan kata lain, teks ini telah menjadi bagian dari kuasa yang menjungkirkan ketidakadilan sosial di masyarakat yang kapitalistik.

\section{DAFTAR PUSTAKA}

[1] Bloomaert, Jan. 2007. Discourse: Key Topics in Sociolinguistics. Cambridge: Cambridge University Press. 
[2] De Fina, Anna, Schiffrin, Deborah, \& Bamberg, Michael. 2006. "Introduction". Dalam De Fina, Anna, Schiffrin, Deborah, \& Bamberg, Michael. (eds.). Discourse and Identity. London: Routledge.

[3] Dornyei, Zoltan. 2007. Research Methods in Applied Linguistics: Quantitative, Qualitative, and Mixed Methodologies. Oxford: Oxford University Press.

[4] Eriyanto. 2000. Analisis Wacana; Pengantar Analisis Teks Media. Yogyakarta: LKiS.

[5] Halliday, M. A. K, \& Hasan, Ruqaiya. 1976. Cohesion in English. London: Longman.

[6] Hall, Stuart. 2002. "Foucault: Power, Knowledge, and Discourse". Dalam Wetherell, Margaret, Taylor, Stephanie, \& Yates, Simeon. (eds.). Discourse, Theory and Practice: A Reader. London: Sage Publications.

[7] Hardiman, F. Budi. 2009. Kritik Ideologi: Menyingkap Pertautan dan Kepentingan Bersama Jürgen Habermas. Yogyakarta: Penerbit Kanisius.

[8] Hoffman, Th. R. 1993. Realms of Meaning: An Introduction to Semantics. New York: Longman.

[9] Jørgensen, Marianne, \& Phillips, Louise. 2002. Discourse Analysis as Theory and Method. London: Sage Publications.

[10] Kridalaksana, Harimurti, et al. 1999. Tata Bahasa Deskriptif Bahasa Indonesia: Sintaksis. Depok: Fakultas Sastra UI.

[11] Kusuma. 2010. "Sosok Jurgen Habermas di Mata Fransisco Budi Hardiman". http://www.surabayapost.co.id/?mnu=berita\&act=v iew\&id=6d1 ca411 fcbc6a21484877d59be651db\&je nis $=\mathrm{d} 82 \mathrm{c} 8 \mathrm{~d} 1619 \mathrm{ad} 8176 \mathrm{~d} 665453 \mathrm{cfb} 2 \mathrm{e} 55 \mathrm{f0}$, diunduh 15 Mei 2010

[12] Maybin, Janet. 2002. "Language, Struggle, and Voice: The Bakhtin/Volosinov Writings." Dalam Wetherell, Margaret, Taylor, Stephanie, \& Yates, Simeon. (eds.). Discourse, Theory and Practice: A Reader. London: Sage Publications.
[13] Newmark, Peter. 1988. The Textbook of Translation. Hertforshire: Prentice Hall.

[14] Notess, Greg R. 2002. "The Blog Realm: News Sources, Searching with Daypop, and Content Management". Technology Collection. Vol. 26. No. 5. Sep/Oct 2002.

http://search.proquest.com/docview/199923152/ful ltextPDF/2FB1747928124C49PQ/1?accountid=86 28, diunduh 04 Mei 2016.

[15] Sugiyono. 2010. Metode Penelitian Kuantitatif, Kualitatif, dan $R \& D$. Bandung: Alfabeta.

[16] Tallerman, Maggie. 1998. Understanding Syntax. New York: Oxford University Press.

[17] Thompson, J. B. (ed.). 1982. Habermas: The Critical Debates. London: The Macmillan.

[18] Vaezi, Reza, Torkzadeh, Gholamreza, \& Chang, Jerry Cha-Jan. 2011. "Understanding the Influence of Blog on the Development of Social Capital." The DATA BASE for Advances in Information Systems, Vol. 42, No. 3, August 2011.

[19] Van Dijk, Teun. 1996. "Discourse, Power, and Access". Dalam Caldas-Coulthard, Carmen, \& Coulthard, Malcolm. (eds.) Texts and Practices. London: Routledge, hlm. 85.

[20] Van Dijk, Teun. 2002. "Principles of Critical Discourse Analysis". Dalam Wetherel, Margaret, Taylor, Stephanie, \& Yates, Simon. (eds.). Discourse Theory and Practice. London: Sage Publication, hlm. 300.

[21] Zed, Mestika. 2014. Metode Penelitian Kepustakan. Jakarta: Yayasan Pustaka Obor Indonesia.

Surat Kabar

[22] "Prita Ingin Perkara Pidana Juga Dicabut: RS Omni Internasional Alam Sutera Cabut Gugatan Perdata" Kompas, 12 Desember 2009.

[23] "Uang Koin Peduli Prita: Prita Lelah Mencari Keadilan”, Kompas, 5 Desember 2009. 